\title{
ALIEN PLANTS ARE LESS PALATABLE TO PEST HERBIVORES THAN NATIVE PLANTS: EVIDENCE FROM CAFETERIA EXPERIMENTS IN SEARCH OF SUITABLE PLANT SPECIES TO RESTORE DEGRADED ECOSYSTEMS
}

\author{
MOULDI GAMOUN $\otimes^{1,2}$, MOUNIR LOUHAICHI ${ }^{2}$ \\ ${ }^{1}$ Department of Ecology and Animal Biology, University of Vigo, Vigo, 36310 Pontevedra, Spain; e-mail: gamoun.mouldi@yahoo.fr \\ ${ }^{2}$ International Center for Agricultural Research in the Dry Areas (ICARDA) Tunis, Tunisia; e-mail: M.Louhaichi@cgiar.org \\ $\bowtie$ Corresponding author
}

Received: 26 July 2019 / Accepted: 24 October 2019

\begin{abstract}
Gamoun M., Louhaichi M.: Alien plants are less palatable to pest herbivores than native plants: evidence from cafeteria experiments in search of suitable plant species to restore degraded ecosystems. Ekológia (Bratislava), Vol. 40, No. 1, p. 16-24, 2021.

Nowadays, the ecology and evolutionary potential of alien species are the subjects of several ecological studies. The goal of this study was to compare the feeding preference of Arion ater on seedlings and leaves of alien and native plant species. Seedlings of three native species and one alien species were offered to slugs individually and in combination. Afterward, leaf discs from the native and alien species collected from the same source site of slug's habitat were offered individually and in combination for slugs. When the new plant emerges, it constitutes a generous source of potential food and slugs would even feed on seedlings, which are not particularly palatable. Nonetheless, when given a choice, slug often preferentially feeds on some food items while ignoring others. Alien plants are more resistant to herbivory than native plants. There is a general tendency for alien species to be less palatable than native species. In general, slugs may eat a wide range of seedlings that are much more attractive than mature plants of the same species. Therefore, the native herbivores were found to attack native plants and promoted alien plants. Consequently, highly unacceptable alien species such as Eucalyptus globulus may play an important role in the restoration process.
\end{abstract}

Key words: Eucalyptus globulus, feeding, herbivory, native.

\section{Introduction}

Alien species are altering the world's natural ecosystems and often reduce diversity and cause economic losses in agriculture (Mack et al., 2000; Sakai et al., 2001; Downey, 2008; Mason et al., 2009). Through the terrestrial globe, thousands of invasive alien plant species have been introduced to native ecosystems worldwide throughout history, both intentionally and unintentionally. Nowadays, the ecology and evolutionary potential of alien species are of interest to several environmental managers, and the effects of biological invasions on native communities and ecosystems are a major priority in ecology (Wardle et al., 2011; Simberloff et al., 2012; Baranová et al., 2017). Due to their faster growth, several studies use alien species to restore areas that have been heavily degraded (Ewel, Putz, 2004; Konaikova, Vakarenko, 2020). Many studies show that several herbivores were found to use alien plants, but their impact was small on alien than on native plants. There are many types of interactions between animal and plant where herbivores gains and profits from consuming plants whereas the plants are damaged.

Herbivory is considered the central focus of the organization of biotic communities (Marquis, 1992; Janzen, 1970; Grime, 2002). Although the effects of vertebrate herbivores on plant communities are frequently studied, the effects of invertebrates are important as well (Clear-Hill, Silvertown, 1997). Among these invertebrate herbivores, terrestrial molluscs, such as slugs, are not the only invertebrates to feed on plants and are some of the most important grazers, which have been the subject of several studies. Because these molluscs, mainly slugs, are known to attack seedlings (Hanley et al., 1995a; Hitchmough, Wagner, 2011; Barlow et al., 2013) and can profoundly exert an impact on native plant recruitment and consequently adult species composition (Hanley et al., 1996a).

In recent years, slugs have become ever more important, partly because several species are becoming agricultural and horticultural pests and partly because they have proved to be useful experimental animals. Several works that have attempted to determine the feeding behavior of herbivorous molluscs have tended to focus on the acceptability of various plants as food in both the field and laboratory (Grime et al., 1968; Dirzo, 1980; Dirzo, Harper, 1982; Mølgaard, 1986; Cook, Radford, 1988; Rueda et al., 1991; Hanley et al., 1995b; Fenner et al., 1999; Hitchmough, Wagner, 2011). Fenner (1987) suggests that the attack is more likely to result in the death of the seedling and elimination of grazing in several communities reduces seedling deaths dramatically. 
It is clear that slugs are not indiscriminate feeders but actively choose certain foods in preference to others (South, 1992). Upon arrival at a food source, many of the same chemicals that served as the attractants also stimulate feeding (Thomas, 1986), although food arousal may be short-lived (Tuersley, 1989). For example, Taylor (1902-1907) learned that most slugs are omnivorous and described how Arion ater rejected 39 out of 197 foods. Furthermore, Fromming (1954) provided a great deal of information about the range of plants consumed by slugs and their preferences and described $A$. ater as a polyphagous species. However, subsequent investigations have shown that slugs are capable of a high degree of selection in their feeding behavior and could potentially have great effects on seedling recruitment of some species (Buschmann et al., 2005; Strauss et al., 2009; Hanley, 2004; Hanley et al., 1995b; Hulme, 1996a; Edwards, Crawley, 1999; Wilby, Brown, 2001; Maze 2009; Scheidel, Bruelheide, 2005). Rathcke (1985) suggests that slugs exert a strong selective pressure on the morphology, phenology, and defenses of native plants. Seedlings are more palatable than adult plants, as they contain a lower concentration of secondary metabolites (Hanley et al., 1995a; Fenner et al., 1999) and morphological factors influence feeding behavior, with epidermal cell wall thickness and hairiness related to palatability (Scheidel, Bruelheide, 1999). The effect of secondary plant metabolites is in this connection indisputable (CrawfordSidebotham, 1972; Rhoades, Cates, 1976; Mølgaard, 1986) and has even been considered as one of the driving forces in macroevolution (Cronquist, 1977; Gottlieb, 1982).

In northern Spain, since the last century, Eucalyptus globulus was introduced in extensive plantation from Australia for afforestation and agroforestry activities. Climate and soil conditions are particularly known to the success of development of eucalyptus in this region. On the contrary, the effect of herbivory on the invasive potentiality of this species has yet to be widely experimentally assessed. The success or failure of the invasion of exotic species may be affected by herbivory (Maron, Vilá, 2001; Keane, Crawley, 2002; Shea, Chesson, 2002; Levine et al., 2004; Bruno et al., 2005; Parker et al., 2006; Nuňez et al., 2008).

The objective of the experiment described in the present paper is an attempt to compare the palatability of three native species and one alien species to slug. More precisely, the purpose of this study was to test the food preference for alien plants Eucalyptus globulus in gastropod herbivore.

\section{Material and methods}

\section{Slugs}

Arion ater is a large terrestrial gastropod mollusc belonging to the family Arionidae with an average length is approximately $10-15 \mathrm{~cm}$ when mature. Ten adult $A$. ater, weighing an average of almost $19.5 \mathrm{~g}$, were collected from the forest located near the University of Vigo, Spain. All slugs were kept individually in clear plastic boxes $(40,30$, and $25 \mathrm{~cm})$, with the base covered with moist soil and sprayed with fresh water every day to ensure high humidity and prevent dehydration throughout each of the experiments. The slugs were fed with fresh leaves for at least 2 weeks to ensure acclimation prior to use in experiments.
The environment was maintained at an ambient temperature of laboratory $\left(\approx 25^{\circ} \mathrm{C}\right)$.

\section{Seedling preferences}

Seeds of one alien species and three native species (Eucalyptus globulus, Plantago lanceolata, Lotus pedunculatus, and Brassica rapa) were set to germinate separately in aluminum trays $(20 \times 15 \times 5 \mathrm{~cm}$ deep $)$ filled with soil and maintained in the laboratory.

Eucalyptus globulus is an alien species in Spain and is the most productive forest species in Galicia (northwest Spain) and more than 200,000 ha are covered by this species in pure stands (Fernández et al., 2009). Plantago lanceolata, Lotus pedunculatus and Brassica rapa are native and very common species that frequently share the habitat with Eucalyptus globulus.

As Plantago lanceolata and Lotus pedunculatus, Brassica rapa is a common native species in the area that is frequent in open areas such as roadsides or abandoned fields, where Eucalyptus globulus seedlings frequently establish. All species germinated within 2-4 days. Prior to beginning the experiment, ten seedlings of each species were transplanted in ten pots after the appearance of the first true leaves. The same pots were used with $20 \times 15 \times 5 \mathrm{~cm}$ deep, and each contained $1 \mathrm{~kg}$ soil.

In other ten plots, five seedlings of each species were transplanted in each plot, so that each plot contains a mix of 20 seedlings, five of each species. The seedling then provides abundant food for the slugs.

Where the seedlings were approximately 15 days old, they were offered to the slugs. In the first part of the experiment, each animal was offered ten seedlings per species at once for 24 $\mathrm{h}$ and four species were tested in total. In the second part of the experiment, five seedlings of each species were offered in combination to each animal for consumption for a period of three days for testing of preference feeding.

\section{Leaf disc feeding}

In the second experiment, we studied one alien species and three native species: E. globulus, Plantago lanceolata, Lotus pedunculatus and Salix atrocinerea.

Leaf discs were cut from fresh, adult leaves of all species and offered to Arion ater in Petri dishes $(\varnothing=9 \mathrm{~cm})$. In each dish, five $(\varnothing=10 \mathrm{~mm})$ leaf discs of each plant species were weighed and placed on wet filter paper. Slugs were deprived of food for $24 \mathrm{~h}$ prior to testing. On the day of testing, one dish of leaf discs was given separately to each slug and allowed to feed for a period of approximately $24 \mathrm{~h}$. Afterward, each slug was offered a combination of leaf discs of four different plant species. In the combined feeding experiment, each Petri dish containing five leaf discs from each species plants were offered simultaneously to the slugs in a cafeteria experiment for three days. Thus, the tens slugs were simultaneously fed either (1) five discs of $E u$ calyptus globulus, (2) five discs of Plantago lanceolata, (3) five discs of Lotus pedunculatus, (4) five discs of Salix atrocinerea, and (5) all four species.

On the following day of each trial, the leaf discs consumed were reweighed to assess the amounts eaten by the slugs. The undamaged discs avoided by slug are used as control discs in order to prevent changes in the weight of leaf due to dehydra- 


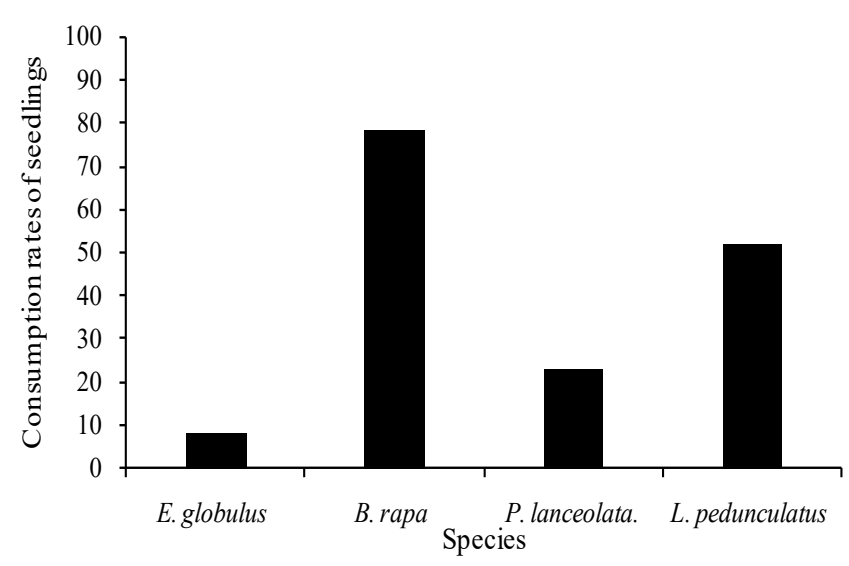

Fig. 1. The consumption rate of four seedlings types by Arion ater on seedlings of Eucalyptus globulus $(n=10)$, Plantago lanceolata $(n=10)$, Lotus pedunculatus $(n=10)$ and Brassica rapa $(n=10)$.

tion. Nevertheless, we have found that dehydration losses are negligible during treatment. Samples of leaf were oven-dried at $70{ }^{\circ} \mathrm{C}$ to measure the dry mass.

The data were analyzed using IBM SPSS statistics 20. Data were subjected to one-way or two-way ANOVA and LSD test to analyze the difference among treatments with the significant differences at $P \leq 0.05$.

\section{Results}

\section{Seedling preferences}

In our seedling preference trials, all seedlings attacked by slugs completely removed all aboveground biomass of the plant and were totally consumed.

When Arion ater was offered each species individually for $24 \mathrm{~h}$, there were significant differences in palatability between species $(F=14.098 ; P<0.0001)$. Preference for seedlings of Brassica rapa was significantly higher than the preference for Lotus pedunculatus, Plantago lanceolata, and Eucalyptus globulus (Fig. 1). Seedlings of E. globulus was significantly less preferred than all the other species. There was a significant difference in preference between E. globulus and Brassica rapa, between Eucalyptus globulus and Lotus pedunculatus, between Brassica rapa and Plantago lanceolata, between Brassica rappa and Lotus pedunculatus, and between Plantago lanceolata and Lotus pedunculatus, whereas there was no significant difference in the preference between Eucalyptus globulus and Plantago lanceolata. Approximately, the consumption rate of Brassica rapa was $78 \%( \pm 7.8)$ seedlings, $52 \%( \pm 12)$ seedlings of Lotus pedunculatus, 23\% ( \pm 7.7$)$ of seedlings of Plantago lanceolata, and $8 \%( \pm 2.9)$ seedlings of Eucalyptus globulus.

When offered a choice between seedlings from four species for three days, a two-way ANOVA on seedling consumption showed interaction between seedlings types and times $(F$ $=3.765 ; P=0.002)$ and significant difference between seedling types $(F=3.562 ; P=0.017)$, and between time $(F=8.936 ; P$ $<0.0001)$.

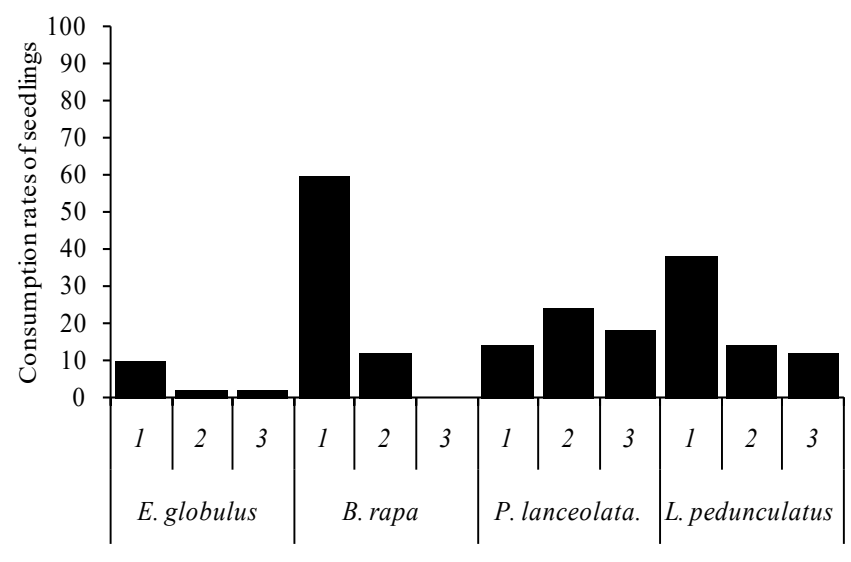

Fig. 2. Consumption rate of Arion ater in the choice experiment on seedlings of Eucalyptus globulus $(\mathrm{n}=10)$, Plantago lanceolata $(\mathrm{n}=10)$, Lotus pedunculatus $(\mathrm{n}=10)$ and Brassica rapa $(\mathrm{n}=10)$ per day over the 3 days' test.

A 24 -h feeding showed a consumption of $30.5 \%$ of seedlings by slugs. The second day induced the consumption of $13 \%$ of seedlings, which is maintained at a lower level during the third following day with about $8 \%$ of seedlings (Fig. 2).

During the first day of feeding by Arion ater, the most consumed plant was Brassica rapa. On average, the consumption of B. rapa was $60 \%$ of seedlings, $38 \%$ of seedlings of Lotus pedunculatus, $14 \%$ of seedlings of Plantago lanceolata and $10 \%$ of seedlings of Eucalyptus globulus.

On the second day, the most consumed plant was Plantago lanceolata. On average, the consumption rate of $P$. lanceolata was $24 \%$ of seedlings, $14 \%$ of seedling of Lotus pedunculatus, $12 \%$ of seedlings of Brassica rapa, and $2 \%$ of seedlings of Eucalyptus globulus. On the third day, the rate of consumption becomes very low and the most consumed plant was Plantago lanceolata. On average, the consumption rate of $P$. lanceolata was $18 \%$ of seedlings, $12 \%$ of seedlings of Lotus pedunculatus, $0 \%$ of seedlings of Brassica rapa and 2\% of seedlings of Eucalyptus globulus.

After three days, $72 \%$ of Brassica rapa plants had been consumed (seedlings were completely consumed by seven slugs), $64 \%$ of Lotus pedunculatus had been consumed, $56 \%$ of Plantago lanceolata had been consumed and 14\% of Eucalyptus globulus had been consumed.

\section{Leaf disc preferences}

The consumption rate varied according to plant species between $0 \%$ for E. globulus and $60 \%$ for Plantago lanceolata. There were significant differences in the palatability based on leaf consumption rates $(F=11.986 ; P<0.001)$.

The palatability or acceptance by $A$. ater in each of the tens treatments for $24 \mathrm{~h}$ varied considerably among plant species (Fig. 3). The total proportion of feeding during the treatment period was $0 \%$ for Eucalyptus globulus, $4 \%$ for Salix atrocinerea, $25 \%$ for Lotus pedunculatus and 60\% for Plantago lanceolata. Within the $24 \mathrm{~h}$ of experimental feeding, leaves of $P$. lanceolata had the highest rate of consumption, indicating that this is the most preferred. Within the four species of leaves, P. lanceolata 


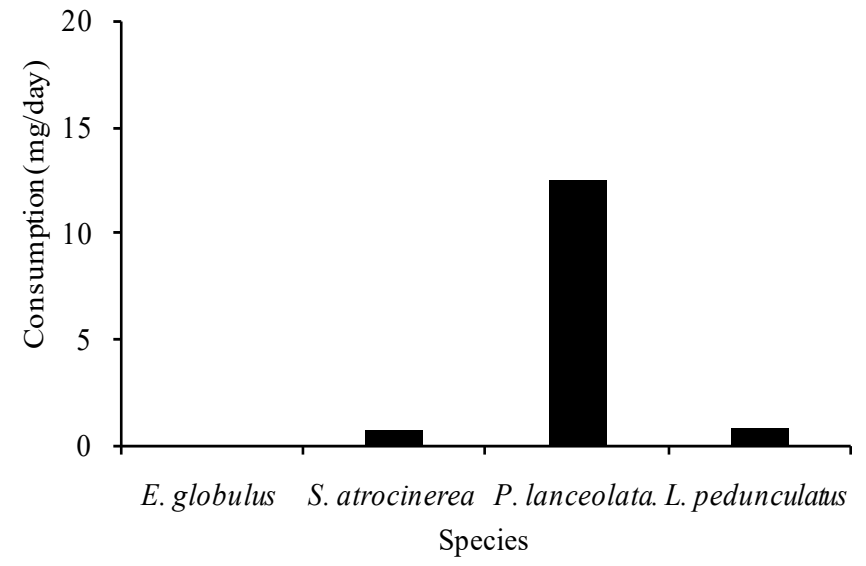

Fig. 3. Consumption rate of Arion ater on leaves of Eucalyptus globulus $(\mathrm{n}=10)$, Plantago lanceolata $(\mathrm{n}=10)$, Lotus pedunculatus $(\mathrm{n}=10)$ and Salix atrocinerea $(\mathrm{n}=10)$.

was the only species to differ significantly from the other species. The rate of consumption (\%) was found to be significantly greater in this species compared to the three other species. A comparison of all discs leaf using LSD also showed that only $P$. lanceolata differed substantially in the rate of consumption ( $P$ $<0.0001$ ).

In this feeding trial, when slugs were offered a single food, P. lanceolata was the only species most consumed and Lotus pedunculatus and Salix atrocinerea were the two species less consumed, while Eucalyptus globulus was the only species in this trial that was not consumed.

When offered the choice between leaf discs from four plants species for three days, Arion ater showed high feeding preferences between species $(F=6.729 ; P<0.0001)$. The foliage consumption was dependent on time $(F=4.419 ; P=0.014)$ and the interaction was significant $(F=4.388 ; P=0.01)$. When given a choice, slug often preferentially feed on some food items while ignoring others. Plantago lanceolata was obviously consumed by the slugs from the first day. Lotus pedunculatus appeared to be eaten in modest amounts, but the result was variable enough that the mass eaten was or was not statistically significant. Eucalyptus globulus and Salix atrocinerea appeared not to be eaten at all periods (Fig. 4). Arion ater clearly preferred Plantago lanceoltata and avoided Eucalyptus globulus and Salix atrocinerea, while it neither preferred nor avoided Lotus pedunculatus.

\section{Discussion}

Cafeteria experiments can afford appropriate information about selective slug herbivory for a broad range of plants. Our results demonstrate that Arion ater preference varies among plant species. It is important to consider that intrinsic plant properties can affect feeding preferences and food choice (e.g., nutrient content, plant growth phenology, toughness) (Lodge, 1991; Newman, 1991; Rosenthal, Berenbaum, 1992; Lodge et al., 1998). The results of the first experiment of seedling preference indicated that there is a significant difference between alien and native plant species. There is a general tendency for alien species to be less palatable than native species.

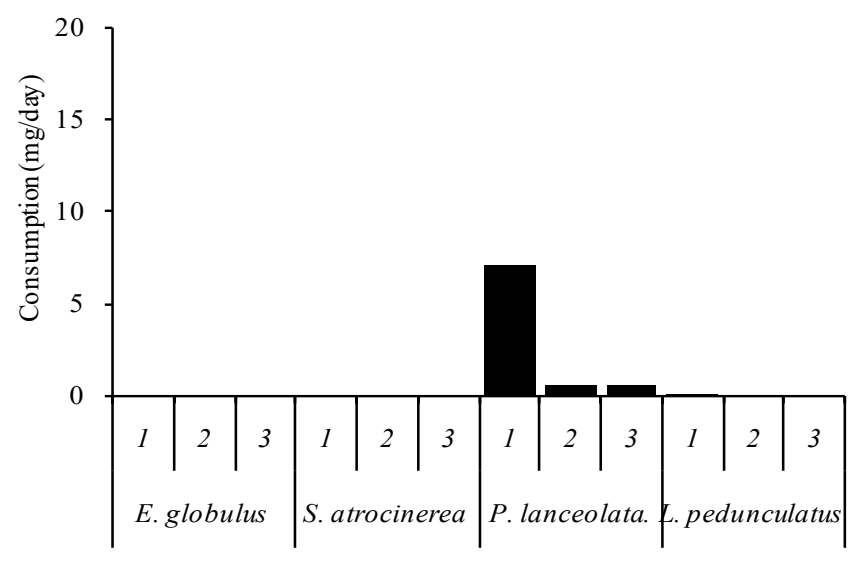

Fig. 4. Consumption rate of Arion ater in the choice experiment on leaves of Eucalyptus globulus $(\mathrm{n}=10)$, Plantago lanceolata $(\mathrm{n}=10)$, Lotus pedunculatus $(\mathrm{n}=10)$ and Salix atrocinerea $(\mathrm{n}=10)$ per day over the 3 days' test.

The results of seedling feeding experiments indicate that the slugs prefer seedlings than mature plants. When the new plant emerges, it constitutes a generous source of potential food and slugs would even feed on seedlings which are not particularly palatable. Our present finding is suggested by several previous studies (Hanley et al., 1995b; Byers, Bierlein, 1982; Barker, 1989). Likewise, when the slugs eat the plant, the whole seedling is removed. Whatever the type of plant, slugs have preferences for newly emerged seedlings.

A number of studies have confirmed that plant species vary consistently in their relative acceptability to generalist seedling herbivores and was largely driven by chemical cues (Hanley et al., 1995a,b, 1996a,b; Hanley et al., 2011; Hanley, 2004; Fenner et al., 1999). In general, herbivores tend to be more selective and use the same range of the native plant. A comparison of the number of seedlings of the studied species eaten showed a high susceptibility of native species to slug feeding such as Brassica rapa. Arion ater showed clear preferences for particular seedling and more than $78 \%$ of Brassica rapa was completely eaten. For many of Brassicaceae, slugs appear to be the main herbivore (Buschmann et al., 2002; Briner, Frank, 1998) and can be a limiting factor for seedling recruitment (Moshgani et al., 2014) although the fact that mustard oils they contain are known to be toxic to herbivores (Rees, Brown, 1992; Briner, Frank, 1998) and characterized by the glucosinolate-myrosinase defense system against herbivore attack (Talekar, Shelton, 1993). It is shown that Glucosinolates are a major component of $B$. rapa (Cartea et al., 2012; Padilla et al., 2007) and could explain their higher palatability by slugs.

Even though slugs were given a choice, B. rapa (78\%) was mostly eaten, followed by Lotus pedunculatus (52\%), Plantago lanceolata (23\%), and Eucalyptus globulus (8\%). For instance, among 16 species studied by Kozłowski and Jaskulska (2014), the most damaged plants were Brassica rapa. The degree of acceptance to the alien species seedlings of Eucalyptus globulus after three days was significantly the least, being around $10 \%$, decreasing to about $2 \%$ after three days.

E. globulus is the least consumed species by Arion ater. It might be expected that this species contains tannin as suggest- 

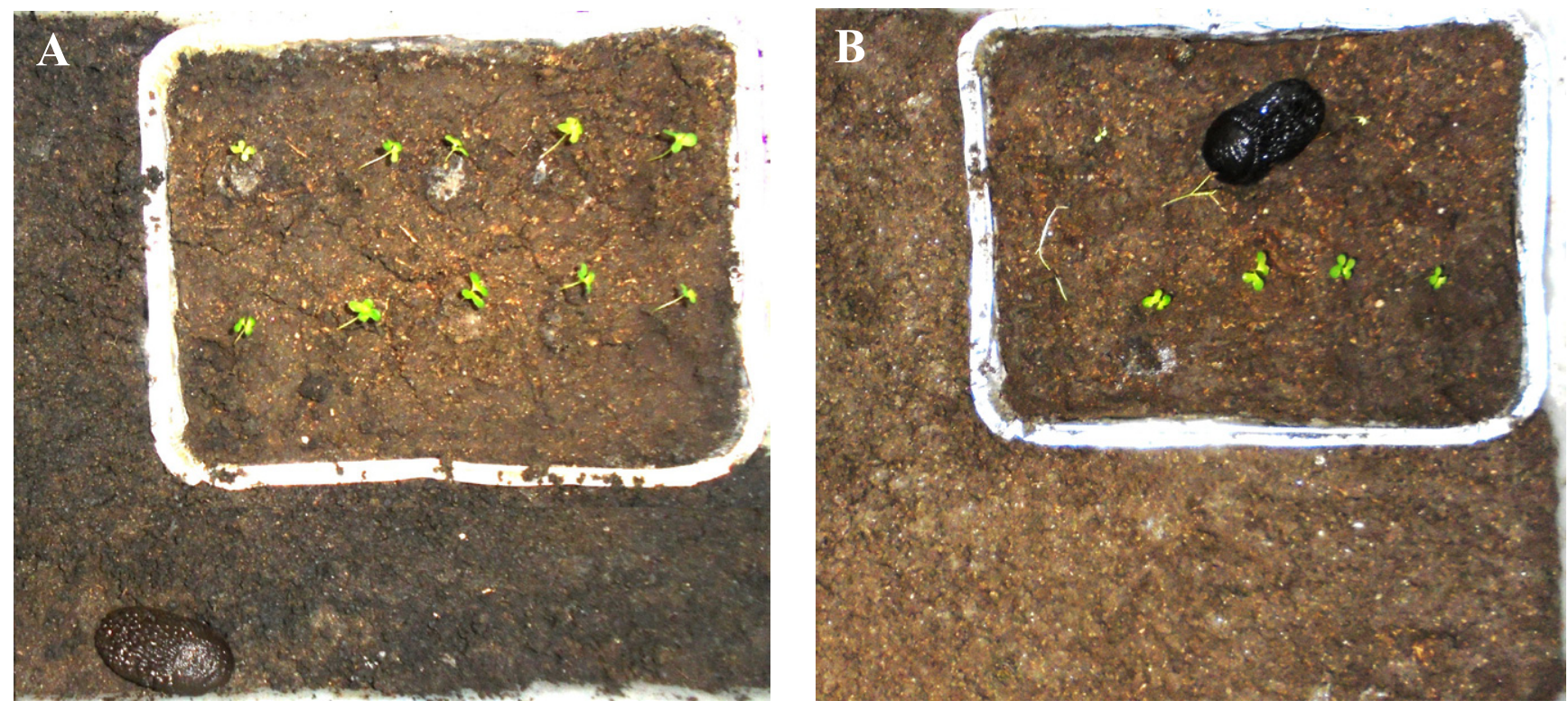

Fig. 5. Seedling of Eucalyptus globulus avoided by slug when given alone (A) and when given the choice with native species (B).

ed by Rapley et al. (2008) and that foliar tannins were operating as a chemical defence in Eucalyptus globulus against herbivory feeding. When plant contains tannin and phenolics, they are avoided by molluscs (Mølgaard, 1986), whereas previous studies noted that tannins impaired protein digestion and nitrogen balance (Silanikove et al., 1997; Decandia et al., 2000). Feeny (1970) found that tannin reduces load either directly through toxicity or growth alteration or directly through reduction of palatability. In general, the chemical compound content of seedling differs both quantitatively and qualitatively from that of the foliage of the mature plants (Boland et al., 1982; Doran, 2002). These differences are significant because seedlings may often be more susceptible to slugs than adult leaves.

The laboratory estimates for individual slugs in the present investigation gave a mean of $14.04 \mathrm{mg} /$ day. The most number of leaves that were eaten by slug is of Plantago lanceolata with an average of $12.44 \mathrm{mg} /$ day. However, at six individual slugs, leaf discs were consumed completely at $20.74 \mathrm{mg} /$ day.

These studies have found the converse that leaf discs of $P$. lanceolata offered singly are consumed more and faster than when offered in combination. These native species were to be highly palatable to Arion ater. From the previously limited results, the consumption rate of $A$. ater does not appear to be greatly different from those quoted for molluscs by other studies. Jenning and Barkham (1976) found that for A. ater the consumption rate was $20.15 \mathrm{mg} /$ day. Hunter (1968) estimated that for A. hortensis, it was $13.7 \mathrm{mg} /$ day. Discus rotundatus consumed $9.4 \mathrm{mg} /$ day (Mason, 1970) and Agriolimax reticulates can consume $60.9 \mathrm{mg} /$ day (Pallant, 1970).

Other studies have shown that Plantago lanceolata were quite unacceptable to slugs (Dirzo, 1980; de Nooij, Mook, 1992; Hulme, 1996b) but greatly eaten by Helix aspersa (Grime et al., 1996) and by Deroceras reticulatum (Peters et al., 2000). Chemical extracts can deter the slug Arion ater (Grime et al., 1968; Mølgaard, 1992). Unlike in previous experiments, among the four species studied, Plantago lanceolata is one of the most preferred foods for Arion ater. When only some species were offered to slugs, they were able to avoid or break the plant's defensive armor.

No-choice feeding studies conducted in our laboratory showed that the alien species Eucalyptus globulus are unacceptable to Arion ater. This is shown by previous studies in which mature leaves are generally considered to be avoided by molluscs (Briner, Frank, 1998; Hanley et al., 1996b). Furthermore, Lotus pedunculatus and Salix atrocinerea were mostly strongly avoided and were significantly less consumed than Plantago lanceolata. Previous experiments found that plants from Plantaginaceae showed a more uncertain pattern, sometimes with a high palatability, sometimes with a low one for different plant species, and also with variation in the acceptability of the same plant for different species of molluscs, and even variation in time with the same animal (Dirzo, 1980; Mølgaard, 1986). Furthermore, $P$. lanceolata was consumed extensively and was one of the most consumed species when slugs were given a choice. Neither specific leaf area nor foliar chemical composition and flavonoids content was able to explain why consumption patterns changed when slugs were offered a choice of food sources. Our experiment shows that consumption of the Arion ater, also used in the present study, was significantly influenced by the quality of available food. Likewise, we found that the duration of feeding was somewhat influenced by food quality, which is different from that found in another study on the slug Laevicaulis alte (Raut, Panigrahi, 1990).

Thus, it is not surprising that in choice feeding tests, these three species were not eaten by Arion ater. The structure of leaves may contribute to avoidance of slug feeding. The leaf roughness of Eucalyptus globulus and Salix atrocinerea and the hairy leaves of Lotus pedunculatus may have reduced their palatability. In our experience, we observed a great variation in the consumption rate of Plantago lanceolata. This species had 
different compounds such as phenolic compounds (caffeic acid derivative) (Mølgaard, 1986) and phenylpropanoid glycoside verbascoside at levels up to $9 \%$ of dry matter (Fajer et al., 1992), which is preferred by Arion refus and the snail Helix pomatia.

The leaf roughness of Eucalyptus globulus and Salix atrocinerea can present a serious problem to much herbivores, which can experience difficulty in getting a good grip on the leaf surface and which can affect palatability. For example, young leaves of Eucalyptus globulus possess epicuticular wax, which makes the leaves slippery and reduces adherence of herbivores (Walters, 2011). Therefore, we can suggest that the avoidance of mature leaves was likely related to the higher amount of indigestible fiber they contained. This, in turn, could make it difficult for the insects to feed (Brennan, Weinbaum, 2001). Martin and Juniper (1970) found that a greater number of all angiosperm species contain "extra" chemicals such as sterols and flavonoids, mixed in with the cuticular wax. It seems likely that these substances have a protective role. Furthermore, Eucalyptus are a species that produce sclerophyllous leaves that are tough, low in nitrogen, high in fiber and in secondary compounds, also with leaves unpalatable to herbivores because they contain toxic and indigestible compounds. Consequently, the leaves of Eucalyptus are regarded as having a low nutritive value, or food quality, to herbivores (Morrow, 1983).

Our results are in agreement with some other previous studies (Hill, Kotanen, 2009; Dawson et al., 2009; Liu, Stiling, 2006), indicating that native herbivores prefer native plants (Fig. 5). However, other studies have found herbivores preferring exotic over native plants (Maron, Vilà, 2001; Parker et al., 2006; Ricciardi, Ward, 2006).

In general, the alien species E. globulus is less palatable food both at the seedling or mature leaves state, and native trees tend to suffer more from herbivory than alien trees. In fact, it appears that the introduction of Australian eucalyptus to other world regions is a success. This success is certainly due in part to get away from specialist insects that exert heavy damage in the native region. In regions to which these trees have been introduced, the effect of native insects is rare (Ohmart, Edwards, 1991). In California, for example, eucalyptus that has introduced since a long time ago has been free of plant diseases and herbivorous insects that feed on them in Australia until recently.

As it is widely known, alien plants are notorious for the damage they can do to natural communities. However, only a small proportion has become aggressive invaders in natural areas. $E$. globulus have the potential that they may adapt and evolve within their new environment. This alien plant may escape herbivore damage in their new area that native plants that are more susceptible to herbivore selection.

Successful experiments in which alien seedlings are resistant to herbivore demonstrate the potential of this plant species and that may be one of the characteristics of many successful invaders (Buschmann et al., 2006). The introduction of alien plants species can also shift seedling-herbivore interaction. Tallamy (2004) shows that alien plants can negatively affect herbivore abundance. For example, in Australia, their origin area, E. stellulata was attacked by 48 species (Morrow, LaMarche, 1978) but by only one when it was introduced in California (Strong et al., 1984). Because of the lack of co-evolved relationship, herbivores may feed less on the new species (Liu, Stilling, 2006). Therefore, the native herbivores were found to attack native plants and pro- moted alien plants. Alien plants can benefit from the suppression of native plants and can be the avoided food source and may thus increase invasive species establishment. Seedlings of highly acceptable species may be a limiting factor influencing recruitment at restoration sites (Barlow et al., 2013).

However, climate, soil, and the biotic traits of the habitat being invaded are not the only active determinant of alien plant establishment: alien plant establishment success also will be affected by herbivory.

We propose that knowledge of the most successful seedling establishment of E. globulus in a new region could improve the cost effectiveness and efficiency of conservation and restoration programs. In turn, this knowledge of the most successful of seedling establishment is determined by herbivore selectivity. However, contrary to common practice, it is not always necessary to remove all alien species to obtain excellent restoration results. Previous studies suggest that the effectiveness of using alien plants to restore native forest depends on site conditions and plantation species used (Bernhardt-Reversat, 2001; Bone et al., 1997, Haggar et al., 1997; Powers et al., 1997). Nevertheless, some Eucalyptus species appear to have a neutral or positive effect on native colonization (da Silva et al., 1995). Using alien plants, such as E. globulus, could be recommended for restoring degraded sites where physical conditions or herbivory pressure seriously limit native plants' establishment. The alien plants might work perfectly well or better than native plants where restoration of ecosystem services is the main goal (Ewel, Putz, 2004).

\section{Conclusion}

Arion ater is a selective herbivore given a choice of seedling and mature plant leaves. Our observations demonstrate that native invertebrate herbivore preferred native plants and had no preferences for alien versus native plants.

Native species were more preferred than alien species. Furthermore, the seedling was more preferred and very attractive to slugs than mature leaves regardless of the type of plants. Similarly, slugs may eat a wide range of seedling for the reason that seedling represents the freshest food, more accessible to be eaten, and have a less toxic composition.

Although slugs do not often result in the killing of the mature plants, mortality can occur, especially when slugs feed on seedlings. Seedlings are mostly affected by slugs, which often lead to the disappearance of many plants in the natural ecosystem or cultivated plants.

Otherwise, molluscs may be considered as the real pest of plants establishment and can profoundly influence species diversity. Therefore, where slug populations are high, control measures are necessary during the period of germination and initial establishment. The alien species Eucalyptus globulus is less palatable food both at the seedling or mature leaves state, and native trees tend to suffer more from herbivory than alien trees. In fact, it appears that the introduction of E. globulus to other world regions is a success and could be recommended for restoring degraded sites where physical conditions or herbivory pressure seriously limit native plants establishment.

\section{Acknowledgements}

This work was supported by the project Erasmus Mundus E-GOV$T N$, the International Center for Agricultural Research in the Dry 
Areas (ICARDA) and the CGIAR Research Program on Livestock (CRP Livestock). The opinions expressed in this work belong to the authors, and do not necessarily reflect those of ICARDA, or CGIAR.

\section{References}

Baranová, B., Fazekašová, D. \& Manko P. (2017). Variations of selected soil properties in the grass fields invaded and uninvaded by invasive goldenrod (Solidago canadensis L.). Ekológia (Bratislava), 36(2), 101-111. DOI: 10.1515/eko-2017-0009.

Barker, G.M. (1989). Slug problems in New Zealand pastoral agriculture. In I. Henderson (Ed.), Slugs and snails in World Agriculture (pp 59-68). London: British Crop Protection Council.

Barlow, S.E., Close, A.J. \& Port G.R. (2013). The acceptability of meadow plants to the slug Deroceras reticulatum and implications for grassland restoration. Ann. Bot., 112, 721-730. DOI: 10.1093/aob/mct086.

Bernhardt-Reversat, F. (Ed.) (2001). Effect of exotic tree plantations on plant diversity and biological soil fertility in the Congo savanna: with special reference to eucalypts. Bogor: Center for International Forestry Research.

Boland, D.J., Brophy, J.J., Flynn, T.M. \& Lassak E.V. (1982). Volatile leaf oils of Eucalyptus delegatensis seedlings. Phytochemistry, 21, 2467-2469. DOI: 10.1016/0031-9422(82)85242-4.

Bone, R., Lawrence, M. \& Magombo Z. (1997). The effect of Eucalyptus camaldulensis (Dehn) plantation on native woodland recovery on Ulumba Mountain, southern Malawi. For. Ecol. Manag., 99, 83-99. DOI: 10.1016/S0378-1127(97)00196-5.

Brennan, E.B. \& Weinbaum S.A. (2001). Stylet penetration and survival of three psyllid species on adult leaves and "waxy" and "de-waxed" juvenile leaves of Eucalyptus globulus. Entomol. Exp. Appl., 100, 355-366. DOI: 10.1046/j.1570-7458.2001.00883.x.

Briner, T. \& Frank T. (1998). The palatability of 78 wildflower strip plants to the slug Arion lusitanicus. Ann. Appl. Biol., 133, 123-133. DOI 10.1111/j.1744-7348.1998.tb05808.x.

Bruno, J.F, Fridley, J.D., Bromberg, K.D. \& Bertness M.D. (2005). Insights into biotic interactions from studies of species invasions. In D.F. Sax J.J. Stachowicz \& S.D. Gaines (Eds.), Species invasions: Insights into ecology, evolution and biogeography (pp. 13-40). Sinauer Associates.

Buschmann, H., Edwards, P.J. \& Dietz H. (2002). Does herbivory by slugs influence the invasiveness of perennial Brassicaceae? Bull. Geobot. Inst. ETH, 68, 73-81.

Buschmann, H., Keller, M., Porret, N., Dietz, H. \& Edwards P.J. (2005). The effect of slug grazing on vegetation development and plant species diversity in an experimental grassland. Funct. Ecol., 19, 291-298. DOI: $10.1111 /$ j.1365-2435.2005.00960.x.

Buschmann, H., Edwards, P.J. \& Dietz H. (2006). Responses of native and invasive Brassicaceae species to slug herbivory. Acta Oecol., 30 126-135. DOI: 10.1016/j.actao.2005.11.006.

Byers, R.A. \& Bierlein D.L. (1982). Feeding preferences of three slug species in the laboratory. Melscheimer Entomol. Ser., 32, 5-11.

Cartea, M.E., Haro, A., Obregón, S., Soengas, P. \& Velasco P. (2012). Glucosinolate variation in leaves of Brassica rapa crops. Plant Foods Hum. Nutr., 67, 283-288. DOI: 10.1007/s11130-012-0300-6.

Clear-Hill, B.H. \& Silvertown J. (1997). Higher-order interaction between molluscs and sheep affecting seedling numbers in grassland. Acta Oecol., 18, 587-596. DOI: 10.1016/S1146-609X(97)80043-4.

Cook, A. \& Radford D.J. (1988). The comparative ecology of four sympatric limacid slugs in Northern Ireland. Malacologia, 28, 131-146.

Crawford-Sidebotham, T.J. (1972). The role of slugs and snails in the maintenance of the cyanogenesis polyrnorphisms of Lotus corniculatus and Trifolium repens. Heredity, 28, 405-411. DOI: 10.1038/ hdy. 1972.52 .

Cronquist, A. (1977). On the taxonomic significance of secondary metabolites in angiosperms. In K. Kubitzki (Eds.), Flowering plants. Plant systematics and evolution. Vol. 1. (pp. 179-189). Vienna: Springer. DOI: 10.1007/978-3-7091-7076-2_12.

Da Silva, M.C., Scarano, F.R. \& Cardel F.S. (1995). Regeneration of an Atlantic forest formation in the understorey of a Eucalyptus grandis plantation in south-eastern Brazil. J. Trop. Ecol., 11, 147-152. DOI: $10.1017 /$ S0266467400008518.
Dawson, W., Burslem, D.F.R.P. \& Hulme P.E. (2009). Herbivory is related to taxonomic isolation, but not to invasiveness of tropical alien plants. Divers. Distrib., 15, 141-147. DOI: 10.1111/j.1472-4642.2008.00527.x. de Nooij, M.P. \& Mook J.H. (1992). Interactions with other organisms. In P.J.C. Kuiper \& M. Bos (Eds.), Ecological studies analysis and synthesis (pp. 52-68). Vol. 89. Plantago: a multidisciplinary study. Berlin: Springer-Verlag.

Decandia, M., Sitzia, M., Cabiddu, A., Kababya, D. \& Molle G. (2000). The use of polyethylene glycol to reduce the anti-nutritional effects of tannins in goats fed woody species. Small Ruminant Res., 38, 157-164. DOI: $10.1016 /$ S0921-4488(00)00145-0.

Dirzo, R. (1980). Experimental studies on slug-plant interactions: I. The acceptability of thirty plant species to the slug Agriolimax caruaneae. J. Ecol., 68, 981-998. DOI: 10.2307/2259470.

Dirzo, R. \& Harper J.L. (1982). Experimental studies on plant-slug interactions. III. Differences in the acceptability of individual plants of Trifolium repens to slugs and snails. J. Ecol., 70, 101-117. DOI: $10.2307 / 2259867$.

Doran, J.C. (2002). Genetic improvement of eucalypts. With special reference to oil-bearing species. In J.J.W. Coppen (Ed.), Eucalyptus. The genus eucalyptus (pp. 421). London: CRC Press. DOI: $10.1201 / 9780203219430$.

Downey, P.O. (2008). Determination and management of alien plant impacts on biodiversity: examples from New South Wales, Australia. In B. Tokarska-Guzik, J. Brock, G. Brundu, L. Child, C. Daehler \& P. Pyšek (Eds.), Plant invasion: Human perceptions, ecological impacts and management (pp. 369-385). Leiden: Backhuys Publishers.

Edwards, G.R. \& Crawley M.J. (1999). Herbivores, seed banks and seedling recruitment in mesic grassland. J. Ecol., 87, 423-435. DOI: 10.1046/j.1365-2745.1999.00363.x.

Ewel, J.J. \& Putz F.E. (2004). A place for alien species in ecosystem restoration. Frontiers of Ecology and Environment, 2, 354-360. DOI: 10.1890/1540-9295(2004)002[0354:APFASI]2.0.CO;2.

Fajer, E.D., Bowers, M.D. \& Bazzaz F.A. (1992). The effect of nutrients and enriched $\mathrm{CO}_{2}$ environments on production of carbon-based allelochemicals in plantago: A test of the carbon/nutrient balance hypothesis. Am. Nat., 140, 707-723. DOI: 10.1086/285436.

Feeny, P. (1970). Seasonal changes in oak leaf tannins and nutrients as a cause of spring feeding by winter moth caterpillars. Ecology, 51, 565-581. DOI: 10.2307/1934037.

Fenner, M. (1987). Seedlings. New Phytol., 106 (Suppl.), 35-47. DOI: 10.1111/j.1469-8137.1987.tb04681.x.

Fenner, M., Hanley, M.E. \& Lawrence R. (1999). Comparison of seedling and adult palatability in annual and perennial plants. Funct. Ecol., 13, 546-551. DOI: 10.1046/j.1365-2435.1999.00346.x.

Fernández, C., Vega, J.A., Bará, S., Beloso, C., Alonso, M. \& Fonturbel T. (2009). Nitrogen mineralization alter clearcutting and residue management in a second rotation E. globulus Labill. stand in Galicia (NW Spain). Ann. For. Sci., 66, 807. DOI: 10.1051/forest/2009076.

Fromming, E. (1954). Biologie der mittel-europaischen Landgastropoden. Berlin: Duncker \& Humblot.

Gottlieb, O.R. (1982). Micromolecular evolution, systematics and ecology. Berlin: Springer.

Grime, J.P., McPherson-Stewart, S.F. \& Dearman R.S. (1968). An investigation of leaf palatability using the snail Cepaea nemoralis L. J. Ecol., 56, 405-420. DOI: $10.2307 / 2258241$.

Grime, J.P., Cornelissen, J.H.C., Thompson, K. \& Hodgson J.G. (1996). Evidence of a causal connection between anti-herbivore defence and the decompositionrate of leaves. Oikos, 77, 489-494. DOI: 10.2307/3545938.

Grime, J.P. (2002). Plant strategies, vegetation processes, and ecosystem properties. Chichester: John Wiley \& Sons.

Haggar, J., Wightman, K. \& Fisher R. (1997). The potential of plantations to foster woody regeneration within a deforested landscape in lowland Costa Rica. For. Ecol. Manag., 99, 55-64. DOI: 10.1016/S0378 1127(97)00194-1.

Hanley, M.E., Fenner, M. \& Edwards P.J. (1995a). The effect of seedling age on the likelihood of herbivory by the slug Deroceras reticulatum. Funct. Ecol., 9, 754-759. DOI: 10.2307/2390248.

Hanley, M.E., Fenner, M. \& Edwards P.J. (1995b). An experimental field study of the effects of mollusc grazing on seedling recruitment and survival in grassland. J. Ecol., 83, 621-627. DOI: 10.2307/2261630. 
Hanley, M.E., Fenner, M., \& Edwards P.J. (1996a). The effect of mollusc grazing on seedling recruitment in artificially created grassland gaps. Oecologia, 106, 240-246. DOI: 10.1007/BF00328604.

Hanley, M.E., Fenner, M. \& Edwards P.J. (1996b). Mollusc grazing and seedling survivorship of four common grassland plant species: the role of gap size, species and season. Acta Oecol., 17, 331-341.

Hanley, M.E. (2004). Seedling herbivory and the influence of plant species richness in seedling neighbourhoods. Plant Ecol., 170, 35-41. DOI: 10.1023/B:VEGE.0000019022.48043.56.

Hanley, M.E., Collins, S.A. \& Swann C. (2011). Advertising acceptability: is mollusk olfaction important in seedling selection? Plant Ecol., 212, 727-731. DOI: 10.1007/s11258-010-9845-3.

Hill, S.B. \& Kotanen P.M. (2009). Evidence that phylogenetically novel nonindigenous plants experience less herbivory. Oecologia, 161, 581-590. DOI: $10.1007 / \mathrm{s} 00442-009-1403-0$.

Hitchmough, J. \& Wagner M. (2011). Slug grazing effects on seedling and adult life stages of North American Prairie plants used in designed urban landscapes. Urban Ecosystems, 14, 279-302. DOI: 10.1007/s11252011-0154-y.

Hulme, P.E. (1996a). Herbivory, plant regeneration, and species coexistence. J. Ecol., 84, 609-615. DOI: 10.2307/2261482.

Hulme, P.E. (1996b). Herbivores and the performance of grassland plants a comparison of arthropod, mollusc and rodent herbivory. J. Ecol., 84 43-51. DOI: $10.2307 / 2261698$.

Hunter, P.J. (1968). Studies on slugs of arable ground. III. Feeding habits. Malacologia, 6, 391-399.

Janzen, D.H. (1970). Herbivores and the number of tree species in tropical forests. Am. Nat., 104, 501-528. DOI: 10.1086/282687.

Jenning, T.J. \& Barkham J.P. (1976). Quantitative study of feeding in woodland by the slug Arion ater. Oikos, 27, 168-173. DOI: 10.2307/3543448.

Keane, R.M. \& Crawley M.J. (2002). Exotic plant invasions and the enemy release hypothesis. Trends Ecol. Evol., 14, 164-170. DOI: 10.1016/ S0169-5347(02)02499-0.

Konaikova, V.O. \& Vakarenko O.V. (2020). The alien fraction of the woody flora of Yelanetskyi Step Nature Reserve, southern Ukraine. Ekológia (Bratislava), 39(4),322-332. DOI: 10.2478/eko-2020-0026.

Kozłowski, J. \& Jaskulska M. (2014). The effect of grazing by the slug Arion vulgaris, Arion rufus and Deroceras reticulatum (Gastropoda: Pulmonata: Stylommatophora) on leguminous plants and other small-area crops. Journal of Plant Protection Research, 54, 258-266. DOI: 10.2478/ jppr-2014-0039.

Levine, J.M., Adler, P.B. \& Yelenik S.G. (2004). A meta-analysis of biotic resistance to exotic plant invasions. Ecol. Lett., 7, 975-989. DOI: 10.1111/j.1461-0248.2004.00657.x.

Liu, H. \& Stiling P. (2006). Testing the enemy release hypothesis: a review and meta-analysis. Biol. Invasions, 8, 1535-1545. DOI: 10.1007/s10530 005-5845-y.

Lodge, D.M. (1991). Herbivory on freshwater macrophytes. Aquat. Bot., 41 195-224. DOI: 10.1016/0304-3770(91)90044-6.

Lodge, D.M., Cronin, G., Van Donk, E. \& Froelich A.J. (1998). Impact of herbivory on plan standing crop: comparisons among biomes, between vascular and non-vascular plants, and among freshwater herbivore taxa. In E. Jeppesen, M. Sondergaard, M. Sondergaard \& K Christoffersen (Eds.), The structuring role of submerged macrophytes in lakes (pp. 149-174). New York, Berlin, Heidelberg: Spinger. DOI 10.1007/978-1-4612-0695-8.

Mack, R.N., Simberloff, D., Londsdale, W.M., Evans, H., Clout, M \& Bazzaz F.A. (2000). Biotic invasions: causes, epidemiology, global consequences, and control. Ecol. Appl., 10, 689-710. DOI: 10.1890/1051-0761(2000)010[0689:BICEGC]2.0.CO;2.

Maron, J.L. \& Vilà M. (2001). When do herbivores affect plant invasion? Evidence for the natural enemies and biotic resistance hypotheses. Oikos, 95, 361-373. https://www.jstor.org/stable/3547492.

Marquis, R.J. (1992). The selective impact of herbivores. In Fritz, R.S. \& Simms E.L. (Eds.), Plant resistance to herbivores and pathogens (pp. 301-325). Chicago: University of Chicago Press.

Martin, J.T. \& Juniper B.E. (1970). The cuticles of plants. London: Edward Arnold.

Mason, C.F. (1970). Snail populations, beech litter production, and the role of snails in litter decomposition. Oecologia, 5, 215-239. DOI: 10.1007/ BF00344885.
Mason, T.J., French, K. \& Lonsdale W.M. (2009). Do graminoid and woody invaders have different effects on native plant functional groups? J. Appl. Ecol., 46, 426-433. DOI: 10.1111/j.1365-2664.2009.01607.x.

Maze, D.M. (2009). Effect of terrestrial mollusk herbivory on Holocarpha macradenia (Asteraceae) seedlings in California coastal prairie under different clipping regimes. Madrono, 56, 1-7. https://www.jstor.org/stable/41425794

Mølgaard, P. (1986). Food plant preferences by slugs and snails: A simple method to evaluate the relative palatability of the food plants. Biochem. Syst. Ecol., 14, 113-121. DOI: 10.1016/0305-1978(86)90095-5.

Mølgaard, P. (1992). Polymorphism for caffeic acid esters in populations of Plantago major ssp pleisperma. In P.J.C. Kuiper \& M. Bos (Eds.), Ecological studies analysis and synthesis (pp. 192-203). Vol. 89. Plantago: a multidisciplinary study. Berlin: Springer-Verlag.

Morrow, P.A. \& LaMarche V.C. jr. (1978). Tree ring evidence for chronic insect suppression of productivity in subalpine Eucalyptus. Science, 201, 1244-1246. DOI: $10.1126 /$ science.201.4362.1244.

Morrow, P.A. (1983). The role of sclerophyllous leaves in determining insect grazing damage. In Kruger, F.., Mitchell, D.T. \& Jarvis J.U.M. (Eds.), Mediterranean-type ecosystems: The role of nutrients. Berlin: Springer-Verlag.

Moshgani, M., Kolvoort, E. \& de Jong T.J. (2014). Pronounced effects of slug herbivory on seedling recruitment of Brassica cultivars and accessions, especially those with low levels of aliphatic glucosinolates. Basic and Applied Ecology, 15, 607-615. DOI: 10.1016/j.baae.2014.08.011.

Newman, R.M. (1991). Herbivory and detritivory on freshwater macrophytes by invertebrates: a review. Journal of the North American Benthological Society, 10, 89-114. DOI: 10.2307/1467571.

Nuňez, M.A., Relva, M.A. \& Simberloff D. (2008). Enemy release or invasional meltdown? Deer preference for exotic and native trees on Isla Victoria, Argentina. Austral Ecol., 33, 317-323. DOI: 10.1111/j.14429993.2007.01819.x.

Ohmart, C.P. \& Edwards P.B. (1991). Insect herbivory on eucalypts. Ann. Rev. Entomol., 36, 637-657. DOI: 10.1146/annurev.en.36.010191.003225.

Padilla, G., Cartea, M.E., Velasco, P., de Haro, A. \& Ordás, A. 2007. Variation of glucosinolates in vegetable crops of Brassica rapa. Phytochemistry, 68, 536-545. DOI: 10.1016/j.phytochem.2006.11.017.

Pallant, D. (1970). A quantitative study of feeding in woodland by the grey field slug (Agriolimax reticulatus Mul ler). Proceedings of the Malacological Society London, 39, 83-87.

Parker, J.D., Burkepile, D.E. \& Hay M.E. (2006). Opposing effects of native and exotic herbivores on plant invasions. Science, 311, 1459-1461. DOI: $10.1126 /$ science.1121407.

Peters, H.A., Baur, B., Bazzaz, F. \& Körner C. (2000). Consumption rates and food preferences of slugs in a calcareous grassland under current and future $\mathrm{CO}_{2}$ conditions. Oecologia, 125, 72-81. DOI: 10.1007/ PL00008893.

Powers, J.S., Haggar, P.G. \& Fisher F.R. (1997). The effect of overstory composition woody regeneration and species richness in 7-year-old plantations in Costa Rica. For. Ecol. Manag., 99, 43-54. DOI: 10.1016/S03781127(97)00193-X

Rapley, L.P., Allen, G.R., Potts, B.M. \& Davies N.W. (2008). Constitutive or induced defences - how does Eucalyptus globulus defend itself from larval feeding? Chemoecology, 17, 235-243. DOI: 10.1007/s00049-007-0382-z.

Rathcke, B. (1985). Slugs as generalist herbivores: tests of three hypotheses on plant choices. Ecology, 66, 828-836. DOI: 10.2307/1940544.

Raut, S.K. \& Panigrahi A. (1990). Feeding rhythm in the garden slug Laevicaulis alte (Soleolifera: Veronicellidae). Malacol. Rev., 23, 39-46.

Rees, M. \& Brown V.K. (1992). Interactions between invertebrate herbivores and plant competition. J. Ecol., 80, 353-360. DOI: 10.2307/2261017.

Rhoades, D.F. \& Cates R.G. (1976). Towards a general theory of plant anti-herbivore chemistry. Recent Adv. Phytochem., 10,168-213. DOI: 10.1007/978-1-4684-2646-5_4.

Ricciardi, A. \& Ward J.M. (2006). Comment on "Opposing effects of native and exotic herbivores on plant invasions". Science, 313, 298 DOI: $10.1126 /$ science. 1128946

Rosenthal, G.H. \& Berenbaum M.R. (1992). Herbivores: their interactions with secondary plant metabolites. Vol. II. Ecological and evolutionary processes. New York: Academic Press.

Rueda, A.A., Slansky, F. \& Wheeler G.S. (1991). Compensatory feeding response of the slug Sarasinula plebeia to dietary dilution. Oecologia, 88, 181-188. DOI: 10.1007/BF00320809. 
Sakai, A.K., Allendorf, F.W., Holt, J.S., Lodge, D.M., Molofsky, J., With K.A. \& Baughman S. (2001). The population biology of invasive species. Annu. Rev. Ecol. Syst., 32, 305-332. DOI: 10.1146/annurev.ecolsys.32.081501.114037.

Scheidel, U. \& Bruelheide H. (1999). Selective slug grazing on montane meadow plants. J. Ecol., 87, 828-838. DOI: 10.1046/j.13652745.1999.00402.x.

Scheidel, U. \& Bruelheide H. (2005). Effects of slug herbivory on the seedling establishment of two montane Asteraceae species. Flora, 200, 309-320. DOI: 10.1016/j.flora.2004.08.003.

Shea, K. \& Chesson P. (2002). Community ecology theory as a framework for biological invasions. Trends Ecol. Evol., 17, 170-176. DOI: 10.1016/ S0169-5347(02)02495-3.

Silanikove, N., Gilboa, N. \& Nitsan Z. (1997). Interactions among tannins, supplementation and polyethylene glycol in goats given oak leaves: effects on digestion and feed intake. Anim. Sci., 64, 479-483. DOI 10.1017/S135772980001609X.

Simberloff, D., Souza, L., Nunez, M.A., Barrios-Garcia, N. \& Bunn W. (2012). The natives are restless, but not often and mostly when disturbed. Ecology, 93, 598-607. DOI: 10.1890/11-1232.1.

Strauss, S.Y., Stanton, M.L., Emery, N.C., Bradley, C.A., Carleton, A., Dittrich-Reed, D.R., Ervin, O.A., Gray, L.N., Hamilton, A.M., Rogge, J.H., Harper, S.D., Law, K.C., Pham, V.Q., Putnam, M.E., Roth, T.M., Theil, J.H., Wells, L.M. \& Yoshizuka E.M. (2009). Cryptic seedling herbivory by nocturnal introduced generalists impacts survival, performance of native and exotic plants. Ecology, 90, 419-429. DOI: 10.1890/071533.1 .
South, A. (1992). Terrestrial slugs. Biology, ecology and control. London: Chapman \& Hall.

Strong, D.R., Lawton, J.H. \& Southwood R. (1984). Insects on plants: community patterns and mechanisms. Cambridge: Harvard University Press.

Talekar, N.S. \& Shelton A.M. (1993). Biology, ecology and management of the diamondback moth. Annu. Rev. Entomol., 38, 275-301. DOI: 10.1146/annurev.en.38.010193.001423.

Tallamy, D.W. (2004). Do alien plants reduce insect biomass? Conserv. Biol., 18, 1-4. DOI: 10.1111/j.1523-1739.2004.00512.x.

Thomas, J. (1986). The chemical ecology of Biomphalaria glabrata (say): Sugars as attractants and arrestants. Comp. Biochem. Physiol. Part A Physiology, 83, 457-460. DOI: 10.1016/0300-9629(86)90130-1.

Tuersley, M. (1989). How is food arousal manifested in the pond snail Lymnaea stagnalis?: An overview. J. Molluscan Stud., 55, 209-216. DOI 10.1093/mollus/55.2.209.

Walters, D.R. (2011). Plant defense: warding off attack by pathogens, herbivores, and parasitic plants. Blackwell Publishing Ltd.

Wardle, D.A., Bardgett, R.D., Callaway, R.M. \& Van der Putten W.H (2011). Terrestrial ecosystem responses to species gains and losses. Science, 332, 1273-1277. DOI: 10.1126/science.1197479.

Wilby, A. \& Brown V.K. (2001). Herbivory, litter and soil disturbance as determinants of vegetation dynamics during old-field succession under set-aside. Oecologia, 127, 259-265. https://www.jstor.org/stable/4222925 